\author{
Zoja Nowożenowa \\ Gdańsk
}

\title{
PROBLEMY ORGANIZACYJNE I DYDAKTYCZNE SPECJALIZACJI TRANSLATORYCZNEJ NA FILOLOGII ROSYJSKIEJ
}

\footnotetext{
Zarys treści: W artykule analizowane są społeczno-polityczne przesłanki zmian w kształceniu filologa rusycysty. Ważnym komponentem kształcenia rusycysty w Polsce staje się kształtowanie w nim kompetencji tłumaczeniowej. W artykule przeanalizowano organizacyjne oraz dydaktyczne problemy, które powstały w trakcie tworzenia specjalizacji translatorycznej i powołania Zakładu Translatoryki i Komunikacji Międzykulturowej na Uniwersytecie Gdańskim w Instytucie Filologii Wschodniosłowiańskiej. Przedstawiono lingwistyczne, translatorskie i dydaktyczne postulaty, które uważano za priorytetowe przy organizacji specjalizacji.
}

tatus języka rosyjskiego w Polsce jako dyscypliny naukowej i obiektu kształcenia ciągle się zmienia, co jest związane z dynamiką sytuacji społeczno-politycznej w Polsce. Poza tym w ostatnich latach krajowa doktryna kształcenia w Polsce, zatwierdzona w dokumencie „Strategia rozwoju edukacji na lata 2007-2013" (Strategia rozwoju 2005), wniosła znaczące zmiany w rozumienie treści i form kształcenia współczesnego specjalisty, określiła wymogi kwalifikacyjne dla nowych kadr i zażądała modernizacji nauki, co również nie mogło nie odbić się na procesie nauczania języka rosyjskiego. Poważne następstwa dla całej struktury kształcenia w Polsce, w tym i rusycystów, ma już wprowadzany w życie system boloński.

Należałoby również podkreślić, że między Polską i Rosją realizowany jest nieustający transfer informacyjny we wszystkich dziedzinach życia społecz- 
nego: w polityce, kulturze, handlu, ekonomii. Tłumacz staje się dostrzegalną i niezbędną jednostką tego procesu.

Wszystkie wyżej wymienione czynniki nie mogą nie mieć wpływu na treści kształcenia w nauczaniu języka rosyjskiego w Polsce, na formy i zestaw proponowanych dyscyplin, programy, plany, liczbę godzin, rozłożenie właściwych akcentów $\mathrm{w}$ rozumieniu natury $\mathrm{i}$ istoty wybieranych strategii i technologii nauczania. Nie może to także nie wpływać na ogólną koncepcję kształcenia filologa rusycysty.

Ogólną coraz szerzej uświadamianą tendencją w kształceniu filologa rusycysty jest przekazywanie mu wiedzy stosowanej, pragmatyczne nastawienie na nauczanie, wyjście poza granice filologicznego wykształcenia sensu stricto. Pojawiają się takie kierunki jak translatoryka, kulturoznawstwo, krajoznawstwo i turystyka, komunikacja w kontaktach zawodowych, język biznesu, teoria i praktyka przekładu, które ostatecznie związane są z głównym celem nauczania rosyjskiego jako języka obcego - kształtowaniem kompetencji komunikacyjnej w różnych dziedzinach (lingwistycznej, socjolingwistycznej, dyskursywnej, socjokulturowej, społecznej).

Ważnym komponentem kształcenia rusycysty w Polsce jest możliwość kształtowania w nim kompetencji tłumaczeniowej. Należy zaznaczyć, że nauka na specjalizacji translatorycznej nie zrywa z klasycznym wykształceniem filologicznym, lecz rozwija się na jego podstawie. Jednakże w ostatnich latach w zakładach i instytutach filologii rosyjskiej w Polsce coraz częściej pojawiają się dyscypliny związane z przekładem, których zadaniem końcowym jest kształtowanie u studentów rusycystów wiedzy teoretycznej i umiejętności fachowych w dziedzinie przekładu (translatoryki): wykłady z teorii przekładu, wstęp do translatoryki. Na zajęciach z praktycznej nauki języka rosyjskiego nauka przekładu staje się już nie metodą, lecz celem. Opracowywane są poszczególne rodzaje przekładu: przekład ustny i pisemny, przekład tekstów specjalistycznych, tekstów artystycznych, dokumentów.

W odpowiedzi na praktyczne zapotrzebowanie stawiane przez życie $\mathrm{w}$ instytutach i zakładach filologii rosyjskiej stworzona została możliwość nauczenia się zawodu tłumacza. Logicznym zakończeniem tego procesu jest uruchomienie na filologii rosyjskiej specjalizacji translatorycznej, obok glottodydaktycznej, kulturoznawczo-literackiej, językoznawczej. Właśnie tak wygląda sytuacja na Uniwersytecie Gdańskim.

W 2006 roku na Uniwersytecie Gdańskim w Instytucie Filologii Wschodniosłowiańskiej został utworzony Zakład Translatoryki i Komunikacji Międzykulturowej, którego zadaniem jest umożliwienie studentom zdobycia 
wiedzy teoretycznej i umiejętności praktycznych w dziedzinie translatoryki i komunikacji międzykulturowej, szeroko rozumianego transferu międzyjęzykowego, wpływów kultury na proces przekładu, znajomości kultury oraz aktualnych wydarzeń w kraju studiowanego języka (Rosji), rzeczywistości językowej, konwencji językowych i stereotypów w języku rosyjskim. Studenci mają również możliwość nabywania praktycznych umiejętności przekładu tekstów literackich, publicystycznych, naukowych, specjalistycznych (z dziedziny prawa, ekonomii, techniki), urzędowych (administracja) itd. Otrzymują wiedzę i umiejętności w zakresie korzystania ze słowników i technologii komputerowych, zapoznają się z etyczną i organizacyjno-prawną stroną działalności tłumaczy w Polsce (organizacje, wspólnoty, wydania, zabezpieczenie prawne działalności tłumaczy itd.).

Oczekujemy, że specjalizacja ta da naszym absolwentom większą możliwość znalezienia pracy w agencjach tłumaczeniowych, redakcjach, wydawnictwach, na stanowiskach administracyjnych oraz możliwość realizowania się w dziedzinie biznesu. Wiedza i umiejętności w dziedzinie przekładu znacznie poszerzą możliwości polskich rusycystów na rynku pracy i podwyższy ich rolę w międzykulturowym dialogu Polski i Rosji.

Aby wspomniana możliwość mogła być zrealizowana, niezbędny jest przemyślany system nauczania na wybranej specjalizacji. Rozwiązanie tego zadania komplikuje się koniecznością wykonania go w trudnym momencie przemian, w trakcie przejścia na system boloński. Trudności kształcenia związane są również z tym, że wśród naszych studentów są osoby, które studiują na dwóch kierunkach, oraz z tym, że mamy grupy rozpoczynające naukę języka rosyjskiego dopiero na studiach, tak zwane zerówki. Naturalnie prowadzi to do tego, że poziom znajomości języka bardzo często pozostawia wiele do życzenia (ponieważ znacznie skraca się czas jego nauki i opanowania). Stanęliśmy zatem przed skomplikowanym zagadnieniem: czego uczyć i jak uczyć w ramach danej specjalizacji.

Jak wiadomo, nie ma jednoznacznej odpowiedzi na pytanie, czym jest przekład: rzemiosłem, sztuką czy teorią. Interesujący wydaje się fakt, że właśnie tak był zatytułowany referat N.K. Garbowskiego - dziekana wydziału Wyższej Szkoły Przekładu Moskiewskiego Uniwersytetu Państwowego im. Łomonosowa - „Przekład: rzemiosło, sztuka, teoria”, wygłoszony na międzynarodowej konferencji naukowej „ęzyk rosyjski i kultura w zwierciadle przekładu" (Saloniki 2008 r.) (Гарбовский 2008). Kwestia ta ma ogromne znaczenie, gdyż od jej rozwiązania zależy cały proces kształcenia tłumaczy. 
Rosyjski teoretyk przekładu W.N. Komissarow pisze:

Aby urzeczywistnić nauczanie przyszłych tłumaczy, koniecznie trzeba odpowiedzieć [...] na trzy pytania: po co uczyć, czego uczyć i jak uczyć? Jak wynika z doświadczenia - dalej pisze Komissarow - z przekładem mają do czynienia nie tylko nieliczne szczególnie uzdolnione osoby: ogólnie większość uczących się może osiągnąć niezbędny poziom profesjonalny w tej sferze działalności. Oczywiście sukces w przyswajaniu materiału zależy w dużej mierze od organizacji procesu nauczania, programu nauczania i metodyki kształcenia (Комиссаров 2004: 321).

Podstawową wybraną przez nas strategią nauczania jest strategia nauczania rzemiosła w obrębie specjalizacji translatorycznej, kształcenie kultury mowy i kompetencji społeczno-kulturowej dotyczącej kraju, którego języka się uczy. Co więcej, rozumiejąc fakt, iż nasi studenci nie staną się od razu kompetentnymi tłumaczami, zakładamy, że nauka rzemiosła równa się szeroko rozumianemu wprowadzeniu do specjalności tłumaczeniowej (przede wszystkim z języka rosyjskiego na język polski).

W czasie organizacji specjalizacji translatorycznej opieraliśmy się na niektórych, istotnych naszym zdaniem w tej kwestii postulatach lingwistycznych, transaltorycznych i dydaktycznych, jak również na niektórych zasadach ważnych dla rozwiązań organizacyjnych:

1) na pytanie, gdzie przygotowywać przyszłych tłumaczy i czy można to robić na studiach filologicznych, na drugą część pytania należy odpowiedzieć pozytywnie, ponieważ studia filologiczne zwykle mają odpowiednią kadrę pedagogiczną (na studiach filologicznych bardzo często pracują zawodowi tłumacze), co daje możliwość organizacji odpowiedniego procesu dydaktycznego;

2) zadaniem dydaktycznym w ramach specjalizacji jest konieczność zorganizowania sytuacji kształcenia, która ma przybliżyć studentom zawód tłumacza na poziomie psychologicznym, językowym i społeczno-kulturowym;

3) za najlepszą formułę przygotowania przyszłego tłumacza uznać należy skalarność, rozpatrywaną na dwóch płaszczyznach: jako skalarność kompetencji translatorskiej oraz skalarność przygotowania tłumacza: od wprowadzenia w rzemiosło, przez udoskonalanie kwalifikacji tłumacza, do perfekcyjnego opanowania zawodu. Uważamy, że studia licencjackie i magisterskie właściwie są pierwszą skalą procesu kształcenia; 
4) nauka przekładu ma wymiar nie tylko stosowany (przez kształtowanie wśród uczących się niezbędnej kompetencji translatorskiej), pełni ona także ważne funkcje ogólnolingwistyczne i ogólnokształcące;

5) tłumaczenie rozpatrywane jest jako złożony i wielostronny rodzaj działalności intelektualnej, która może mieć różne cele i odbywać się w różnych warunkach i na różne sposoby;

6) jak w przypadku każdej działalności dla realizacji przekładu potrzebna jest odpowiednia wiedza, umiejętności (świadome wykonywani określonych działań) oraz nawyki (półautomatyczne i automatyczne wykonywanie czynności), które powinno się wykształcać w trakcie nauczania;

7) tłumacz może dokonywać przekładu w sposób świadomy (w rezultacie analizy i uzasadnionych wniosków) bądź intuicyjnie. Zdolność do świadomych i intuicyjnych działań translatorskich (kompetencja translatorska) powstaje w procesie nauki i pracy praktycznej;

8) realizacja kompetencji translatorskich odbywa się przez zaangażowanie językowej osobowości tłumacza. Wymaga ona wszechstronnej wiedzy lingwistycznej i kognitywnej, rozległej erudycji ogólnokulturowej, określonych cech psychologicznych, a także umiejętności elokwentnego posługiwania się językiem;

9) zadanie nauczania przekładu polega nie na przyswojeniu pewnych norm, reguł czy recept, które tłumacz mógłby automatycznie stosować we wszystkich przypadkach, lecz w opanowaniu zasad, metod i technik tłumaczenia oraz umiejętności dokonywania wyboru w konkretnych warunkach, do różnych tekstów i w różnych celach;

10) obiektem działalności translatorskiej jest informacja zawarta $w$ tekście wyjściowym. Jednostki językowe tworzące tekst same w sobie nie są obiektem przekładu. Przedstawiona współzależność określa również charakter materiałów dydaktycznych wykorzystywanych do nauki przekładu. Przede wszystkim powinny to być teksty różnego typu, pozwalające na upodobnienie przekładu dydaktycznego do warunków pracy profesjonalnego tłumacza;

11) w procesie nauki przekładu należy uwzględniać nie sposoby tłumaczenia materiału dydaktycznego (tekstów, wypowiedzi, słów), lecz metody rozwiązywania typowych zadań translatorskich oraz strategii poszukiwania indywidualnych, twórczych rozwiązań;

12) w procesie nauczania przed studentami nie stawia się zadania stworzenia jedynie poprawnego (optymalnego) przekładu. Proces nauczania powinien zawierać krytyczną ocenę przekładów dydaktycznych 
oraz wykluczenie wariantów nie do przyjęcia. Zadaniem wykładowcy jest demonstracja błędów opierająca się na semantyczno-porównawczej, kontekstologicznej oraz lingwistyczno-kulturologicznej analizie stylistycznej tekstów oryginału i przekładu. Analiza taka wymaga od studentów znajomości podstawowych terminów i pojęć z zakresu językoznawstwa i przekładu. Wiedzę tę student zdobywa w trakcie opanowywania odpowiednich dyscyplin teoretycznych. Ujawniające się luki uzupełniane są komentarzami wykładowcy na zajęciach z przekładu.

Kierując się tymi postulatami, w ramach specjalizacji translatorycznej zaproponowaliśmy takie dyscypliny i programy jak stylistyka i lingwistyczna analiza tekstu, leksykografia translatoryczna. Programy tych przedmiotów uwzględniają ważne aspekty kształtowania profesjonalnych kompetencji tłumacza, ponieważ zapewniają istotną w działalności translatorskiej umiejętność przedtłumaczeniowej analizy tekstu. Translatoryczna analiza tekstu polega przede wszystkim na określeniu: 1) celu przekładu oraz 2) typu tekstu (styl i gatunek). Pozwala ona wybrać odpowiednią strategię tłumaczenia. Stylistyka zapoznaje ze stylistyczną specyfiką przekładanych tekstów, z ich stylową i gatunkową organizacją, co umożliwia późniejsze dokonywanie lingwistycznej analizy tekstu. Leksykografia translatoryczna przybliża wiedzę o słownikach jako nośnikach informacji translatorycznej. Co więcej, ściśle określiliśmy krąg przedmiotów „translatorskich” sensu stricto. Są to: teoria przekładu (oprócz tego dla wszystkich specjalizacji proponuje się przedmiot wstęp do translatoryki), przekład tekstów specjalistycznych, przekład tekstów medialnych i reklamowych, przekład tekstów literackich, przekład tekstów mówionych, technologia przekładu, organizacja i technika pracy tłumacza (wykorzystanie technologii informatycznych w przekładzie). Magistrantom proponuje się takie dyscypliny, jak: kulturowe aspekty przekładu, przekład tekstów medialnych i reklamowych, przekład tekstów mówionych, przekład tekstów specjalistycznych.

Rozumienie przekładu jako dialogu kultur implikuje zawarcie w kształceniu (w ramach naszej specjalizacji) potężnego komponentu kulturoznawczego, realizującego się na różne sposoby. Są to dyscypliny kulturoznawcze (komunikacja międzykulturowa oraz rosyjski dyskurs), a także akcentowanie w przekazywanym materiale specyfiki międzykulturowych stosunków Rosjan i Polaków (na przykład językowy obraz świata Rosjan i Polaków: aspekt porównawczy), problem osobowości językowych i narodowych, problem stereotypów itp. Jest to także kulturoznawcza i porównawcza analiza w kursie stylistyki i filologicznej analizy tekstu (specyfika zestawu stylów i ich konfigu- 
racji w rosyjskim i polskim języku literackim, specyfika środków stylistycznych w obu językach, zestaw gatunków w różnorodnych sferach stylistycznych, narodowa specyfika organizacji tekstów (urzędowych, dokumentów, umów), specyfika terminologii narodowej w tekstach naukowych, tłumaczenie utrwalonych w języku wyrażeń oraz na przykład zjawisk precedentnych $\mathrm{w}$ tekstach publicystycznych.

Analiza ankiet przeprowadzonych wśród studentów II roku Uniwersytetu Gdańskiego (dane z pracy dyplomowej A. Wysomierskiej 2009) pokazała, że duża część ankietowanych na pytanie „Jaką specjalizację wybrałeś?” odpowiadała - translatoryczną.

Wśród motywów i argumentów wpływających na wybór podawano: 1) specjalizacja stwarza możliwość znalezienia dobrze płatnej pracy; 2) specjalizacja uzupełnia moje drugie wykształcenie; 3) oferta specjalizacji translatorycznej okazała się najbardziej interesująca; 4) na wybór wpłynęła grupa wykładowców prowadzących przedmioty na danej specjalizacji.

Specjalizacja translatoryczna daje studentom możliwość nie tylko realizowania się w charakterze tłumacza praktyka, lecz również kontynuowania kariery naukowej, prowadzenia poszukiwań teoretycznych w tej dziedzinie, również w charakterze doktorantów.

Reasumując, rozumienie nauki o przekładzie jako celu kształcenia wymaga rozwiązań dydaktycznych i organizacyjnych.

\section{Literatura}

Гарбовский, Н.К., 2008, „Перевод: ремесло, искусство, теория”, [w:] Русский язык и культура в зеркале перевода, Москва, с. 112-124.

Комиссаров, В.Н., 2004, Современное переводоведение, Москва.

Strategia rozwoju edukacji na lata 2007-2013, 2005, Ministerstwo Edukacji Narodowej i Sportu.

\section{Organizational and didactic problems of translation specialization at Russian language studies \\ Summary}

The present article analyzes political and social reasons behind changes in the training of specialists in Russian studies. The idea of translation and translator's competence is becoming a noticeable part of the education and training of specialists in 
Russian studies. In the paper the author analyzes organizational and didactic problems that have emerged while organizing the translation specialization at the Department of Translation Studies and Intercultural Communication at the Institute of East Slavonic Languages of the Gdansk University. The author presents linguistic, translation and didactic postulates which were of top priority in the organizational process. 